\title{
THE PROGNOSIS OF PATENT DUCTUS ARTERIOSUS
}

\author{
BY \\ J. BENN \\ From the Department of Medicine, University of Bristol \\ Received June 25, 1947
}

Surgical intervention is becoming more frequent in patients with a patent ductus arteriosus. At first only marked symptoms were accepted indications for surgery, but these are now becoming much more numerous. This change has largely been due to the gradual decrease of the operative mortality and the dramatic cures effected in cases of bacterial endocarditis. Gilchrist (1946) recommended operation on nearly all uncomplicated cases of patent ductus arteriosus between the ages of 7 and 10 years.

The increased risk that the presence of a patent ductus involves is difficult to assess. Surgeons see the more serious cases with symptoms or with infective endocarditis, and the prognosis without operation in such a series is gloomy. Few physicians have published accounts of large numbers. Maud Abbott's (1936) series based on post-mortem records paints too black a picture as patients with infective endocarditis and congestive heart failure tend to end their lives in hospital. Shapiro and Keys (1941, 1943), Shapiro (1944), Wilson and Lubschez (1942), East (1945), and Gilchrist (1945) have all described series of cases but they do not mention how many were referred for symptoms and how many were symptomless. This is important, as if a large number were referred because of symptoms there must be an excess of the more serious cases which naturally gravitate to hospital or the physician's consulting room.

In the present series the diagnosis of uncomplicated patent ductus arteriosus was made only in the presence of a typical machinery murmur in the second left intercostal space with no evidence of any other abnormality on physical, cardiographic, and $x$-ray examination. Forty-six cases have been collected for analysis and divided into two groups. Group A numbers 30 and, save for one woman, aged 23, referred from an ante-natal clinic because of the presence of a machinery murmur, has been collected from a school cardiac clinic. This must include almost every case of patent ductus arteriosus among the younger people of Bristol, whether they had symptoms or not. Group B consists of 16 cases from areas outside Bristol referred in a few cases from school clinics but often because of symptoms. It follows that Group A forms a representative sample of the condition while Group B approximates more nearly to the type of case generally reported.

Sex Incidence. Of the 60 cases of typical patent ductus arteriosus collected by Shapiro and Keys (1943) 14 were males and 46 females. Steinberg, Grishman, and Sussman (1943) found that of 27 cases 11 were male and 16 female. East (1945) had 4 males and 9 females, Gilchrist (1945) 13 males and 15 females, and Hunter (1945) found 4 males and 10 females. The ratio of males to females varies considerably but in all series there is a preponderance of females varying from slight to very marked. In the present series 13 are males and 33 females. These figures agree substantially with those of other authors.

\section{SYMPTOMS}

Maud Abbott (1929) states that a fair proportion are dyspnœic, and that cyanosis, while usually absent, may be present on exertion. Steinberg et al. (1943) found 12 of 27 cases 
complained of breathlessness. Gross (1939) found his were usually undeveloped and often breathless, but that only those with large ducts had symptoms. Gilchrist (1945) found his patients were often breathless without being aware of it until the patent ductus had been closed, and that in only 5 of 28 was there no limitation of physical capacity. Bullock, Jones, and Dolley (1939) found that only 2 of their 11 cases had no symptoms; all the others had palpitation and were easily tired.

In the present series only 8 children have symptoms at present. Four are slightly breathless on exertion; 3 are easily tired; 5 become slightly blue on occasions; 2 suffer from frequent colds, and only 1 did not play games. In addition 2 children are subject to asthma. Three have more than one symptom. The 30 in Group A include 6 with symptoms, while the 12 surviving members of Group B contain 2 with symptoms. Five of Group B have had bacterial endocarditis and only 1 of these is alive now; this last child was cured by penicillin and is now symptom free. Thus, 7 of the 16 cases in Group B have at some time had symptoms attributable to a patent ductus arteriosus.

\section{Physical Signs}

Cases have been described, without murmurs or with systolic murmurs only, that have been proved to have a patent ductus arteriosus post-mortem. Some of these descriptions are of doubtful accuracy as they were before the existence of the typical machinery murmur was recognized, but others are well authenticated. The question of absent murmurs is dealt with later. Descriptions of cases with systolic murmurs only are particularly common before 1910 . Typical examples are by Gerhardt (1867), Wasastjerna (1874), Darier (1885), Thomson and Drummond (1900), Simmons (1906), Carpenter (1908), Goodman (1910), Motzfeldt (1913), Wessler and Bass (1913), Weiss (1931), Touroff and Vessell (1940), and Chapman and Robbins (1944).

Shapiro (1944) drew up the following list of the chief findings in cases of patent ductus arteriosus - the presence of a machinery murmur, a systolic thrill in the pulmonary area, an enlarged pulmonary artery, enlarged pulsating pulmonary vessels, a large heart, an increase of the pulse pressure, stunting of growth, absence of cyanosis and of clubbing of the fingers, a normal electrocardiogram, and the presence of heart disease from early childhood. He states that a thrill is usually present (53 of his 62 cases), but may be absent if the ductus arteriosus is small. Gross (1940) also says that a thrill is usually present but that the physical signs of patent ductus arteriosus are frequently not present until the age of 3 years.

In the present series the above criteria have been used in diagnosis. A machinery murmur has been present in all, and all are over 3 years of age. Of the 46 cases 30 had a systolic thrill; 19 of the 30 in Group A had a thrill at some time, but in 3 it vanished with increasing age; in Group B, 11 had a thrill and in 1 it disappeared later. In no case did a thrill become evident if it had been absent earlier. The thrill may have disappeared because the chest wall grew thicker with age, but this does not seem likely as in 2 of the 4 cases examination at intervals of one year showed it to be present on the first and absent at the second occasion. These two lost their thrill by 5 and 6 years of age respectively. In a third case the interval was 4 years. It would seem more likely that some change took place in the volume or mechanics of the circulation.

\section{-Blood Pressure}

Bullock et al. (1939) found that all but one of their 11 cases of uncomplicated patent ductus arteriosus had a high pulse pressure and a low diastolic pressure. Gross (1943) said the diastolic pressure was a measure of the leak and pointed out that among 48 cases, who survived operation for closure of a patent ductus, the diastolic blood pressure which had been low rose to normal after operation. Of their 22 cases, Shapiro and Keys (1941) found only 5 with a pulse pressure of less than 45 and the average was 59 . Among normal people they 
did not find any pulse pressure higher than 45. Shapiro (1944) said the pulse pressure may be normal if the ductus arteriosus is small. In his 60 cases (including the 22 cases just mentioned) he found the pulse pressure normal in 14 , but it was increased in the remaining 46 . Tubbs (1945) found the average diastolic pressure was $50-60 \mathrm{~mm}$. Gilchrist (1945) in his series of 28 cases found the average diastolic pressure below the age of 10 years was 48 , and the average systolic pressure 95; over the age of 11 years the average diastolic pressure was $53 \mathrm{~mm}$. Judson and Nicholson (1914) found that the average diastolic pressure in normal children of 3 to 15 years ranged between 64 and 71 and the systolic pressure between 91 and 106, the pulse pressure being about $30 \mathrm{~mm}$.

Bohn (1938) measured the diastolic blood pressure of cases with a patent ductus arteriosus after exercise and found it fell to nearly zero. This fall has been substantiated by Shapiro and Keys (1941).

Of the 30 cases for whom blood pressure readings are available only 5 have a pulse pressure of less than $45 \mathrm{~mm}$; ; this agrees with the findings of Shapiro and Keys (1941) quoted previously.

TABLE I

The Blood Pressure in Patients with a Patent Ductus Arteriosus and the Effect of Exfrcise

\begin{tabular}{|c|c|c|c|c|c|c|c|c|}
\hline & \multirow{2}{*}{ Age } & \multirow{2}{*}{$\begin{array}{l}\text { Number } \\
\text { of cases }\end{array}$} & \multirow{2}{*}{$\begin{array}{l}\text { Average } \\
\text { pulse } \\
\text { pressure }\end{array}$} & \multirow{2}{*}{$\begin{array}{l}\text { Average } \\
\text { diastolic } \\
\text { pressure }\end{array}$} & \multirow{2}{*}{$\begin{array}{l}\text { Number with a } \\
\text { diastolic pressure } \\
\text { of } 60 \mathrm{~mm} \text {. or } \\
\text { below }\end{array}$} & \multicolumn{3}{|c|}{$\begin{array}{l}\text { Number of cases with a } \\
\text { change of diastolic pres- } \\
\text { sure after exercise }\end{array}$} \\
\hline & & & & & & Fall & Rise & $\begin{array}{c}\text { No } \\
\text { change }\end{array}$ \\
\hline Group A & $\begin{array}{c}15 \text { years or below .. } \\
16 \text { years or above } . . \\
\text { Total } . .\end{array}$ & $\begin{array}{l}10 \\
11 \\
21\end{array}$ & $\begin{array}{l}53 \\
55 \\
-\end{array}$ & $\begin{array}{l}66 \\
74 \\
-\end{array}$ & $\begin{array}{r}3 \\
1 \\
-\end{array}$ & $\begin{array}{l}3 \\
3 \\
6\end{array}$ & $\begin{array}{l}0 \\
2 \\
2\end{array}$ & $\begin{array}{l}3 \\
4 \\
7\end{array}$ \\
\hline Group B & $\begin{array}{c}15 \text { years or below } . . \\
16 \text { years or above } . . \\
\text { Total } \ldots\end{array}$ & $\begin{array}{l}6 \\
3 \\
9\end{array}$ & $\begin{array}{l}69 \\
58 \\
-\end{array}$ & $\begin{array}{l}68 \\
72 \\
\end{array}$ & $\begin{array}{l}1 \\
0 \\
-\end{array}$ & $\begin{array}{l}\mathbf{3} \\
\mathbf{0} \\
\mathbf{3}\end{array}$ & $\begin{array}{l}1 \\
0 \\
1\end{array}$ & $\begin{array}{l}0 \\
1 \\
1\end{array}$ \\
\hline \multicolumn{2}{|c|}{ Grand total } & 30 & - & - & 5 & 9 & 3 & 8 \\
\hline
\end{tabular}

Five cases had diastolic blood pressures of 60 or below; this is contrary to the findings of Tubbs (1945) and Gilchrist (1945) and most of the blood pressure readings come into the range of normal as defined by Judson and Nicholson (1914).

The effect of exercise on the blood pressure is not so easy to obtain as has been suggested. Children and even adults often refuse to exercise to the point of distress. In 3 the diastolic blood pressure rose after exercise (see Table I) and in no case did it fall to nearly zero. Of the 8 cases showing a fall in diastolic pressure the greatest drop was $20 \mathrm{~mm}$., the lowest $5 \mathrm{~mm}$.; and the average $10 \mathrm{~mm}$. The test is sometimes useful, but a rise in the diastolic pressure after exercise does not invalidate the diagnosis of a patent ductus arteriosus.

\section{The Electrocardiogram}

Brody and Randell (1935), Bullock et al. (1940), Touroff and Vessell (1940) and Holmes 1945) have' all reported cases of mild left axis deviation. Many other changes have been reported but similar changes in the cardiogram were found in normal children by Lincoln and Nicholson (1928) and by Perry (1931). Gross (1940) pointed out that right axis deviation suggests the presence of some associated abnormality particularly pulmonary stenosis. Steinberg et al. (1943), among their 27 cases had 4 with left and 8 with right axis deviation. Tubbs (1945) said slight axis deviation was occasionally present. Gilchrist (1945) found left axis 
deviation in 7 of his 13 cases all being below the age of 7 years. East (1945) found the cardiogram normal in all his 13 reported cases. In none of these series are the criteria of normality laid down. The general opinion appears to be that apart from mild left axis deviation the electrocardiograms are normal in this condition.

In the present series the axis deviation index as described by Paul White (1944) was measured. Cardiograms of 40 cases were available and only 2 cases showed axis deviation, there being one example of right and another of left deviation. No other abnormalities were present.

\section{X-RAY EXAmination}

Post-mortem examinations have shown that the pulmonary artery, and either or both ventricles are frequently enlarged. Eppinger and Burwell (1940) X-rayed 9 cases and found the left ventricle was enlarged in 8 , the pulmonary artery prominent in 8 , and that pulmonary congestion was present in 9 . Gross (1940) found the cardiothoracic ratio increased slightly, the pulmonary artery prominent and the lungs engorged. This was confirmed by Donovan et al. (1943) who found that among 50 cases most hearts were enlarged and the lungs congested. Grier (1943), and Steinberg et al. (1943) agreed. Shapiro (1944) in 62 cases found the heart enlarged in 40 and markedly enlarged in 4 of these. Gilchrist (1945) found 7 of his 27 cases did not have enlarged hearts on X-ray examination.

In the present series the normal ratio of the transverse diameter of the heart to the transverse diameter of the chest is taken to be 0.45 in adults and 0.52 in children with a normal variation of 10 per cent. Satisfactory X-rays were available in 15; the bounds of normal were exceeded in only one and the ratio in this was 0.66 . All 15 had prominent pulmonary arteries. The degree of pulmonary congestion was measured by assessing the heaviness of the shadows around the hilum, but the incidence cannot be compared accurately as the variations of the normal are assessed differently by each observer. Of the 30 patients with X-rays suitable for examination, 15 showed congestion and the remainder were normal. In Group A, 8 of 20 cases showed congestion and in Group B, 7 of 10 cases are congested. This suggests that among an unbiased series of cases of patent ductus arteriosus (as opposed to a series containing many with symptoms) increased size of the heart and pulmonary congestion is less common than has so far been reported.

No correlation between the presence of symptoms and the presence of pulmonary congestion was found (Table II).

TABLE II

THE INCIDENCE OF SYMPTOMS

\begin{tabular}{|c|c|c|c|c|c|}
\hline & & & $\begin{array}{l}\text { Number of cases } \\
\text { with symptoms }\end{array}$ & $\begin{array}{l}\text { Number of cases } \\
\text { with no symptoms }\end{array}$ & Total \\
\hline \multicolumn{2}{|c|}{$\begin{array}{l}\text { Pulmonary congestion present } \\
\text { Pulmonary congestion absent }\end{array}$} & $\begin{array}{l}\cdots \\
\cdots\end{array}$ & $\begin{array}{l}4 \\
2\end{array}$ & $\begin{array}{l}11 \\
13\end{array}$ & $\begin{array}{l}15 \\
15\end{array}$ \\
\hline Total & $\ldots$ & $\ldots$ & 6 & 24 & 30 \\
\hline
\end{tabular}

Absence of the Machinery Murmur

Luys (1855) in 1848 saw a woman of 52 years in whom physical examination revealed no murmur; post-mortem the ductus arteriosus was patent. Duroziez $(1862,1863)$ found a woman aged 40 years with early congestive heart failure in whose chest he could hear no cardiac murmurs: the ductus arteriosus was patent, post-mortem. Foulis (1884) had a woman patient of 22 years with the typical basal systolic and diastolic murmurs in whom the murmur disappeared 25 days before she died of bacterial endocarditis. Balfour (1898) described a 
cyanosed and breathless woman, who had a loud systolic murmur over the heart with a thrill over the second and third intercostal spaces to the left of the sternum; fifteen years later the murmur and thrill had disappeared: proof that this was a case of patent ductus arteriosus is hardly complete. Gaylor (1918) described a woman first seen by Babcock in 1898, who had a machinery murmur and thrill at the base of the heart; as the years went by the murmur vanished and post-mortem there was a saccular aneurysm of the aorta and a patent ductus arteriosus.

Gross (1939) said that in some children the ductus closed spontaneously and the diastolic element in the machinery murmur was lost. Shapiro and Keys (1943) described a woman of 46 years in heart failure over whose præcordium they could hear no murmur but post-mortem the ductus was patent. In the same paper they mention having seen 2 cases with the typical murmur that later vanished. Gilchrist (1945) described a boy aged 5 years with the typical murmur which had vanished at 6 years. When first seen his X-ray picture was characteristic of a patent ductus arteriosus but 18 months later it was normal. Jager (1940) and Gibb (1941) each described a woman, aged 55 and 51 respectively, with subacute bacterial endocarditis with no abnormal murmurs: post-mortem, the ductus was blocked in each case by vegetations.

The explanation of these findings appears to vary. Some may be explained by blocking of the ductus by vegetations in cases with infective endocarditis. The X-ray changes in Gilchrist's case appear to be due to actual closure of the duct. Other cases appear to be explained by the onset of heart failure. Some may be explained by thickening of the chest wall, emphysema, increase of adipose tissue, change in hæmodynamics, or in the position of the ductus relative to the chest wall. Gebauer (1943) found at operation that the size of the ductus and the amount of blood going through it varied as the intensity of the physical signs.

In the series under examination, 2 had well established machinery murmurs that have now vanished: neither case ever had a thrill. The first had a typical murmur on repeated examination between the ages of 8 and 13 years, a faint systolic murmur only could be heard at 15 years, and later at 21 years, and now at 25 years no murmur is audible. The second case was first diagnosed at the age of 10 years, a soft basal systolic murmur was heard at 24 , and now 3 years later no murmur can be heard. An X-ray of the first case at 9 years revealed slight pulmonary congestion and the cardio-thoracic ratio was $102 / 212=0 \cdot 48$. The pulmonary artery index, being the distance of the junction of the superior vena cava and the right auricle from the summit of the pulmonary arc, as described by Evans (1943), was $5 \cdot 2 \mathrm{~cm}$. At the age of $25, X$-rays still show some pulmonary congestion, the cardio-thoracic ration is $117 / 263=0.44$, and the pulmonary artery index is $7 \cdot 1 \mathrm{~cm}$. Evans (1943) found the index above $7.0 \mathrm{~cm}$. in only 2 of 52 normal cases. The heart did not become smaller as described by Humphreys (1942) and others after operation. These findings suggest that the ductus is probably still patent. In the second case X-rays are not available. The blood pressure of the first case is $120 / 80$, which does not indicate a leak but does not disprove the diagnosis. The second case has a blood pressure of $120 / 60$, which is unaltered by exercise. Gross (1940) stated that closing the ductus by surgery causes the diastolic blood pressure to rise to normal. This reading, therefore, suggests that the ductus is still patent. Neither patient is obese or emphysematous. No definite conclusions can be drawn, but the findings suggest that in both the ductus arteriosus is still patent.

\section{PHYSIQUE}

Abbott (1929) and Gross (1940) found their cases of patent ductus were usually of poor physique. In his 62 cases Shapiro (1944) found 32 were normally developed, 23 undersized, and 6 were obese. Gilchrist (1945) in 13 children found the physique above average in 2, average in 7 , and below average in 4 .

The height and weight of the present series has been compared with those of healthy children from the same area. The controls were chosen at random from schools scattered all over 
TABLE III

A Comparison of the Heights and Weights of Children having a Patent Ductus Arteriosus WITH NORMAL CONTROLS

\begin{tabular}{|c|c|c|c|c|c|c|c|}
\hline \multicolumn{4}{|c|}{ Cases of patent ductus arteriosus } & \multicolumn{2}{|c|}{ Normal Bristol children } & \multicolumn{2}{|c|}{$\begin{array}{l}\text { Difference of case from } \\
\text { controls }\end{array}$} \\
\hline Group & $\begin{array}{l}\text { Age in years } \\
\text { and sex }\end{array}$ & $\begin{array}{l}\text { Height in } \\
\mathrm{cm} .\end{array}$ & $\begin{array}{l}\text { Weight in } \\
\mathrm{kg} \text {. }\end{array}$ & $\begin{array}{l}\text { Mean height } \\
\text { in } \mathrm{cm} .\end{array}$ & $\begin{array}{l}\text { Mean weight } \\
\text { in } \mathrm{kg} .\end{array}$ & $\begin{array}{l}\text { Height in } \\
\mathrm{cm} .\end{array}$ & $\begin{array}{l}\text { Weight in } \\
\mathrm{kg} .\end{array}$ \\
\hline $\begin{array}{l}\text { A } \\
\text { A } \\
\text { A } \\
\text { A } \\
\text { A } \\
\text { A } \\
\text { A } \\
\text { A } \\
\text { A } \\
\text { A } \\
\text { A } \\
\text { A } \\
\text { A } \\
\text { A } \\
\text { A } \\
\text { A } \\
\text { A } \\
\text { B } \\
\text { B } \\
\text { B } \\
\text { B } \\
\text { B } \\
\text { B } \\
\text { B }\end{array}$ & $\begin{array}{rl}3 & \mathrm{~F} \\
3 & \mathrm{~F} \\
4 & \mathrm{~F} \\
4 & \mathrm{~F} \\
6 & \mathrm{~F} \\
8 & \mathrm{M} \\
9 & \mathrm{~F} \\
9 & \mathrm{~F} \\
10 & \mathrm{~F} \\
12 & \mathrm{~F} \\
12 & \mathrm{M} \\
13 & \mathrm{M} \\
13 & \mathrm{~F} \\
15 & \mathrm{~F} \\
15 & \mathrm{M} \\
16 & \mathrm{~F} \\
17 & \mathrm{~F} \\
9 & \mathrm{M} \\
10 & \mathrm{~F} \\
10 & \mathrm{~F} \\
11 & \mathrm{~F} \\
11 & \mathrm{~F} \\
14 & \mathrm{M} \\
17 & \mathrm{~F}\end{array}$ & $\begin{array}{r}106.0 \\
98.0 \\
116.0 \\
109 \cdot 5 \\
111 \cdot 0 \\
131 \cdot 5 \\
\overline{130 \cdot 5} \\
- \\
- \\
- \\
- \\
\overline{-} \\
178 \cdot 0 \\
160 \cdot 0 \\
170 \cdot 0 \\
134.0 \\
127 \cdot 5 \\
147.0 \\
142.0 \\
\overline{156.0} \\
-\end{array}$ & $\begin{array}{l}14 \cdot 5 \\
14 \cdot 1 \\
17 \cdot 7 \\
15 \cdot 9 \\
20 \cdot 5 \\
25 \cdot 0 \\
27 \cdot 3 \\
25 \cdot 0 \\
30 \cdot 9 \\
27 \cdot 3 \\
33 \cdot 2 \\
29 \cdot 1 \\
28 \cdot 2 \\
50 \cdot 0 \\
56 \cdot 4 \\
57 \cdot 7 \\
41 \cdot 8 \\
24 \cdot 5 \\
20 \cdot 5 \\
47 \cdot 3 \\
25 \cdot 9 \\
38 \cdot 2 \\
42 \cdot 3 \\
54 \cdot 5\end{array}$ & $\begin{array}{c}94 \cdot 4 \\
94 \cdot 4 \\
103 \cdot 5 \\
103 \cdot 5 \\
117 \cdot 4 \\
128 \cdot 5 \\
\overline{133 \cdot 1} \\
- \\
- \\
- \\
- \\
\overline{1} \\
169 \cdot 5 \\
165 \cdot 9 \\
169 \cdot 3 \\
130 \cdot 5 \\
137 \cdot 5 \\
137 \cdot 5 \\
142 \cdot 7 \\
\overline{166 \cdot 2} \\
-\end{array}$ & $\begin{array}{l}15 \cdot 4 \\
15 \cdot 4 \\
16 \cdot 5 \\
16 \cdot 5 \\
21 \cdot 9 \\
26 \cdot 7 \\
29 \cdot 0 \\
29 \cdot 0 \\
31 \cdot 6 \\
40 \cdot 4 \\
37 \cdot 5 \\
45 \cdot 0 \\
43 \cdot 4 \\
52 \cdot 5 \\
57 \cdot 2 \\
55 \cdot 4 \\
58 \cdot 7 \\
28 \cdot 5 \\
31 \cdot 6 \\
31 \cdot 6 \\
35 \cdot 4 \\
35 \cdot 4 \\
50 \cdot 0 \\
58 \cdot 7\end{array}$ & $\begin{array}{c}+11.6 \\
+3.6 \\
+12.5 \\
+6.0 \\
-6.4 \\
+3.0 \\
-2.6 \\
- \\
- \\
- \\
- \\
- \\
+8.5 \\
-5.9 \\
+0.7 \\
+3.3 \\
-10.0 \\
+9.5 \\
-1.8 \\
-10.2 \\
-\end{array}$ & $\begin{array}{r}-0.9 \\
-1.3 \\
+1.2 \\
-0.6 \\
-1.4 \\
-1.7 \\
-1.7 \\
-4.0 \\
-0.7 \\
-13.1 \\
-4.3 \\
-15.9 \\
-15.2 \\
-2.5 \\
-0.8 \\
+2.3 \\
-16.9 \\
-4.0 \\
-11.1 \\
+15.7 \\
-9.5 \\
+2.8 \\
-7.7 \\
-4.2\end{array}$ \\
\hline
\end{tabular}

Bristol (Table III). For each year of age from 3 to 15,50 children of each sex were taken and their height and weight measured. For children of 16 and 17 years only 26 and 10 controls were obtained. The figures for adults are compared with the figures for males and females aged 18, 20, and 25 years given by Cruickshank (1946) (Table IV). For these no statistical analysis has been attempted as there is no adequate series of controls.

The weights and heights of Group A have been analysed statistically because it is believed this group gives a true picture of the condition. The results have not been compared with Group B as there are not enough cases in this group with adequate data.

Weights are available for 17 children in Group A and 15 of these children were below the mean weight of control children of the same age and sex. An analysis of variance was made to determine the significance of the difference between the weights of the children in Group A and the corresponding normal children, i.e. of the same sex and age. It was found that on comparing the 4 abnormal males with the 4 classes of normal males of the same age the significance of the lesser weight in the Group A cases was expressed by $\mathrm{P}<\cdot 05$, i.e. was significant to the usual agreed 5 per cent level. In the case of the 13 females in Group $A$ the significance was overwhelming, being expressed by $\mathrm{P}<\cdot 001$.

Heights are available for 10 children in Group A. Seven cases were above average height for their age and sex, while 3 were below the average. A similar analysis as for weights was made. In the two males the difference in height from the normal was not significant. In the 8 females the significance was expressed by $\mathrm{P}<\cdot 05$, i.e. the Group A cases are taller than the normals.

Prognosis

Abbott (1936) found that of 92 uncomplicated cases of patent ductus examined post-mortem 43 per cent died of heart failure and 30 per cent of subacute bacterial endocarditis. Among 
TABLE IV

A Comparison of Adults having a Patent Ductus Arteriosus with Normal Controls

\begin{tabular}{|c|c|c|c|c|c|c|c|}
\hline \multicolumn{4}{|c|}{ Cases of patent ductus arteriosus } & \multicolumn{2}{|c|}{$\begin{array}{l}\text { Normal adults (from } \\
\text { Cruickshank) }\end{array}$} & \multicolumn{2}{|c|}{$\begin{array}{c}\text { Difference of case from } \\
\text { normal }\end{array}$} \\
\hline Group & Age and sex & $\begin{array}{l}\text { Height in } \\
\mathrm{cm} .\end{array}$ & $\begin{array}{l}\text { Weight in } \\
\text { kg. }\end{array}$ & $\begin{array}{l}\text { Height in } \\
\text { cm. }\end{array}$ & $\begin{array}{l}\text { Weight in } \\
\text { kg. }\end{array}$ & $\begin{array}{l}\text { Height in } \\
\text { cm. }\end{array}$ & $\begin{array}{l}\text { Weight in } \\
\text { kg. }\end{array}$ \\
\hline $\begin{array}{l}\text { A } \\
\text { A } \\
\text { A } \\
\text { A } \\
\text { A } \\
\text { A } \\
\text { A } \\
\text { A } \\
\text { A } \\
\text { B }\end{array}$ & $\begin{array}{ll}20 & \mathrm{~F} \\
22 & \mathrm{~F} \\
23 & \mathrm{~F} \\
25 & \mathrm{~F} \\
25 & \mathrm{M} \\
25 & \mathrm{~F} \\
27 & \mathrm{M} \\
27 & \mathrm{M} \\
31 & \mathrm{~F} \\
33 & \mathrm{~F}\end{array}$ & $\begin{array}{l}160.0 \\
162.5 \\
162.5 \\
172.9 \\
175.4 \\
152.2 \\
167.7 \\
172.9 \\
162.5 \\
160.0\end{array}$ & $\begin{array}{l}58 \cdot 6 \\
58 \cdot 6 \\
52 \cdot 7 \\
55 \cdot 9 \\
62 \cdot 3 \\
42 \cdot 3 \\
59 \cdot 1 \\
65 \cdot 9 \\
50 \cdot 0 \\
45 \cdot 9\end{array}$ & $\begin{array}{l}167 \cdot 7 \\
167 \cdot 7 \\
167 \cdot 7 \\
167 \cdot 7 \\
175 \cdot 4 \\
167 \cdot 7 \\
175 \cdot 4 \\
175 \cdot 4 \\
167 \cdot 7 \\
167 \cdot 7\end{array}$ & $\begin{array}{l}57 \cdot 7 \\
57 \cdot 7 \\
57 \cdot 7 \\
59 \cdot 1 \\
63 \cdot 6 \\
59 \cdot 1 \\
70 \cdot 0 \\
70 \cdot 0 \\
59 \cdot 1 \\
59 \cdot 1\end{array}$ & $\begin{array}{c}-7 \cdot 7 \\
-5 \cdot 2 \\
-5 \cdot 2 \\
+5 \cdot 2 \\
0 \\
-15.5 \\
-7 \cdot 7 \\
-2.5 \\
-5 \cdot 2 \\
-7 \cdot 7\end{array}$ & $\begin{array}{r}+0.9 \\
+0.9 \\
-5.0 \\
-3.2 \\
-1.3 \\
-16.8 \\
-10.9 \\
-4.1 \\
-9.1 \\
-13.2\end{array}$ \\
\hline
\end{tabular}

her 73 cases over 3 years of age 16 per cent died of bacterial endocarditis and 32 per cent of heart failure. In 60 collected cases Shapiro and Keys (1943) found the average age at death of men was 39 years and of women 35 years, i.e. 23 and 28 years respectively less than the normal expectation: 40 per cent died of bacterial endocarditis and 30 per cent of congestive heart failure. Sellors (1945) is even more gloomy and says the average expectation of life is 20 to 25 years. Wilson and Lubschez (1942) followed 38 cases for 20 years and in that time saw no deaths from bacterial endocarditis or congestive heart failure.

In Group A, 29 of the 30 cases were seen before the age of 15 years: the one exception was 23 years old when first seen and had been referred from an ante-natal clinic. At present the youngest person in the series is nearly 4 years old and the oldest 31 years. These cases have been followed for an average of more than 8 years and the average age when last seen was over 16 years. Of the cases in Group B, 9 were first seen before 15 years and 7 at a later age. The youngest in this series is now 7 and the oldest 47 years. These cases have been followed for an average of 8 years. Of these 16 cases 12 are still alive and their average age is 19 years. For the length of time the cases have been followed see Table V.

TABLE V

The Length of Follow Up of Cases of Patent Ductus Arteriosus

\begin{tabular}{llll|c|c}
\hline \multicolumn{2}{l|}{ Time followed in years } & Group A & Group B \\
\hline $0-5$ &. &. &. & 9 & 4 \\
$5-10$ &. &. &. & 7 & 4 \\
$10-15$ &.. &. &. & 6 & 2 \\
$15-20$ &. &. &. & 7 & 0 \\
$20-$ &. &.. &. & 0 & 1 \\
\hline
\end{tabular}

During the period under observation none of the Group A cases died or developed bacterial endocarditis or congestive heart failure. Among the 16 in Group B 1 case was first seen after recovery from bacterial endocarditis and 4 died of this disease; 1 of these 4 developed bacterial endocarditis and was treated with penicillin with apparent success although the blood sedimentation rate remained high. She returned home, but two months later suddenly developed fits and died the same night, presumably from a cerebral embolism due to a still active bacterial endocarditis.

The incidence of bacterial endocarditis ( 5 cases out of 16) in Group B is high because several were referred to hospital because of its presence, and this same reason must explain the high 
incidence of bacterial endocarditis in published figures. The absence of such cases in Group A is striking and suggests that the frequency of bacterial endocarditis among all cases of patent ductus arteriosus must be lower than has so far been accepted. The true incidence must lie between that in the two Groups, but much nearer to that of Group A. The absence of congestive heart failure is not so significant as only a few of the cases have reached an age at which such a complication is likely.

\section{THE INDICATIONS FOR SURGERY}

Hubbard, Emerson, and Green (1939) gave retardation of growth, signs of aortic regurgitation, and cardiac insufficiency as the indications for surgery. Gross (1939) after 50 operations gave as his criteria, poor physique, cardiac embarrassment, bacterial endocarditis, and prevention of bacterial endocarditis. Marvin (1941), Burch (1944), and Tubbs (1945) gave almost the same criteria.

Gross (1940) said that operation caused the physical signs to vanish, the diastolic blood pressure to rise, the activity of the heart to diminish, the weight to increase, the heart size to decrease, and symptoms of heart failure to disappear. Donovan et al. (1943) found on X-ray that the heart size diminished only slightly, if at all, after operation. Hunter (1945) had 12 cases all of which lost their breathlessness and became mentally brighter after operation. Gilchrist (1945) found diminished lung vascularity and reduction in size of the heart in 14 patients who survived operation.

Gross (1943) had 2 deaths in 50 operations. Shapiro (1943) collected 104 reported cases treated surgically, none of which had bacterial endocarditis and found 9 deaths; presumably some of these were taken from Gross's records mentioned above. Gilchrist (1945) had 16 cases operated on with 2 deaths.

The absence of bacterial endocarditis in Group A suggests very strongly that it is much less common than has been described. Most cases lead a normal healthy life. On the other hand many are below average weight. Bacterial endocarditis has become much less dangerous since the discovery of penicillin and the facts published in this paper suggest that operation with its grave risks hardly seems justified merely for the prevention of the possibility of infection. However, cases cured of bacterial endocarditis appear to be proper subjects for operation as they are probably more liable to, or more exposed to infection. The risks of dental extraction or operation on infected tonsils are great but they can probably be almost obviated by cover with penicillin. The operative mortality is still high-possibly as high as, or higher than, the risk of bacterial endocarditis or congestive heart failure.

This investigation suggests that at present operation should only be undertaken in a limited number of cases. The indications for surgery would appear to be: bacterial endocarditis, recovered bacterial endocarditis, cardiac embarrassment, or poor physique.

A similar series of cases will need watching for at least 30 years before a complete answer can be given. It would be very worth while if the numbers were large.

\section{SUMMARY}

A series of 46 cases of patent ductus arteriosus is described, particular attention being paid to 30 cases referred from a school cardiac clinic as these form a representative sample of the condition.

Females predominate over males by more than two to one.

Symptoms are few and rarely serious.

In two cases the classical murmur disappeared without other evidence that the ductus arteriosus had closed. Præcordial thrills sometimes vanish with increasing age. The diastolic blood pressure is usually normal; in only a limited number of cases does it fall after exercise. The electrocardiogram is normal.

Pulmonary congestion is not so common as has been reported. The average body weight is 
significantly below normal. Bacterial endocarditis did not develop among the 30 cases referred from the school cardiac clinic.

Fewer cases should be operated on and the suggested indications for surgery are given.

I wish to acknowledge my indebtedness to Professor C. Bruce Perry without whose help this paper could not have been written, as he allowed me full use of his records and gave me much encouragement and advice; to Mr. H. Todd for great help with statistics; and to Professor Parry, Medical Officer of Health for Bristol, who supplied me with the heights and weights of normal children.

Abbott, M. (1929). Blumer's Bedside Diagnosis.

\section{REFERENCES}

(1936). Atlas of Congenital Heart Disease, New York.

Balfour, G. W. (1898). Clinical Lectures on Diseases of the Heart and Aorta. 3rd ed., Edinburgh, p. 243.

Bohn, H. (1938). Klin. Wschr., 17, 907. Quoted by Gilchrist (1945).

Brody, J. G., and Randell, A. (1935). Ohio State Med., 31, 599.

Bullock, L. T., Jones, J. C., and Dolley, F. S. (1939). J. Pediat., 15, 786.

(1940). J. Thorac. Surg., 9, 413.

Burch, G. E. (1944). Med. Clin. North America, 28, 388.

Carpenter, G. (1908). Proc. Roy. Soc., 2, 163.

Chapman, C. B., and Robbins, S. L. (1944). Ann. intern. Med., 21, 312.

Cruickshank, E. W. H. (1946). Food and Nutrition, E. and S. Livingstone, Table 5, p. 56.

Darier, J. (1885). Bull. Soc. Anat. Paris, 10, 55.

Donovan, M. S., Neuhauser, E. B. D:, and Sosman, M. C. (1943). Amer. J. Roentgen., $50,293$.

Duroziez, P. (1862). C. R. Soc. Biol., Paris, 14, 279.

(1863). Gas. Med. Paris, 18, 451 .

East, T. (1945). Brit. Heart J., 7, 95.

Eppinger, E. C., and Burwell, C. S. (1940). J. Amer. med. Ass., 115, 1262.

Evans, W. (1943). Brit. Heart J., 5, 197.

Foulis, J. (1884). Edin. Med. J., 29, 1117, and 30, 17.

Gaylor, H. D. (1918). Trans. Chicago Path. Soc., 10, 296.

Gebauer, P. W. (1943). Austral. New Zeal. J. Surg., 13, 75.

Gerhardt, C. (1867). Jeraische Z. Med. Naturw., 3, 105. Quoted by Holman (1925).

Gibb, W. T. (1941). N.Y.S. J. Med., 41, 1861.

Gilchrist, A. R. (1945). Brit. Heart J., 7, 1. (1946). Edin. Med. J., 53, 346.

Goodman, E. (1910). Univ. Penn. Med. Bull., 10, 509.

Grier, M. E. (1943). Amer. J. Roentgen., 49, 366.

Gross, R. E. (1939). Ann. Surgery, 110, 321.

(1940). J. Amer. med. Ass., 115, 1257.

- (1940). J. Pediat., 17, 716.

_- (1943). N.Y.S. J. Med., 43, 1856.

Holman, E. (1925): Bull. Johns Hopkins Hosp., 36, 61.

Holmes, H. R. (1945). Brit. J. Radiol., 17, 312.

Hubbard, J. P., Emerson, P. V., and Green, H. (1939). New Engl. J. Med., 221, 481.

Humphreys, G. H. (1942). Surgery, 12, 841.

Hunter, J. B. (1945). Proc. Roy. Soc. Med., 39, 107.

Jager, B. V. (1940). Amer. Heart J., 20, 236.

Judson, C. F., and Nicholson, P. (1914). Amer. J. Dis. Child., 17, 907.

Lincoln, E. M., and Nicholson, G. H. B. (1928). Ibid., 35, 1001.

Luys, J. B. (1855). Bull. Soc. Anat. Paris, p. 229.

Marvin, H. M. (1941). Bull. N.Y. Acad. Med., 17, 737.

Motzfeldt, K. (1913). Dtsch. Med. Wschr., 39, 2037. Quoted by Holman (1925).

Neuburgh, L. H. (1942). Arch. intern. Med., 70, 1033.

Perry, C. B. (1931). Arch. Dis. Childh., 6, 259.

Sellors, T. H. (1945). Lancet, 1, 615.

Shapiro, M. J. (1944). J. Amer. med. Ass., 126, 934.

- and Keys, A. (1941). Internat. Clin., 4, 148.

- (1943). Amer. Heart. J., 25, 158.

Simmons, W. H. (1906). Intercolonial Med. J. Australia, Melbourne, 11, 65.

Steinberg, M. F., Grishman, A., and Sussman, M. L. (1943). Amer. J. Roentgen., 50, 306.

Thomson, J., and Drummond, W. B. (1900). Edin. Hosp. Rep., 6, 57.

Touroff, A. S. W., and Vessell, H. (1940). J. Thorac. Surg., 10, 58.

Tubbs, O. S. (1945). Post-graduate med. J., 21, 158.

Wassastjerna, S. O. (1874). Finska Läkaresällskapats handl. Quoted by Holman (1925).

Weiss, E. (1931). Amer. Heart J., 7, 114.

Wells, H. G. (1908). Amer. J. med. Sci., 136, 381.

Wessler, H., and Bass, M. H. (1913). Ibid., 145, 543.

Wilson, M. G., and Lubschez, R. (1942). J. Pediat., $21,23$.

Wright, G. P., and DeNavasquez, S. (1942). Guy's Hosp. Rep., 91, 69. 